\title{
Johan Heyns as apologeet
}

S A Strauss

\section{ABSTRACT}

\section{Johan Heyns as apologist}

It is well known that Johan Heyns developed not only the theological disciplines of Dogmatics and Ethics. He also published a number of important works in the field of Apologetics. In this article special attention is paid to these books. This investigation leads to the conclusion that Heyns most certainly made a valuable contribution to the way in which Apologetics should be practised. His evaluation of viewpoints which differ from his own is always balanced, although he does not hesitate to point out the dangers in the modernistic worldview that threaten the Christian faith. He impresses one with his knowledge of contemporary philosophy.

\section{TERREINAFBAKENING}

Johan Heyns se teologiese oeuvre is so omvangryk en veelsydig dat ons nog lank nie klaar is met die bestudering daarvan nie. Naas studies oor sy dogmatiek of sy etiek bly daar klaarblyklik genoeg stof oor om ook oor sy apologetiek na te dink.

By so 'n onderwerp is dit natuurlik 'n dringende vraag wat met "apologetiek" bedoel word. Dié begrip kan 'n negatiewe konnotasie hê. In die kerkgeskiedenis is daar voorbeelde van teoloë wat die Bybelse opdrag tot verantwoording (1 Pet 3:15) só verstaan het dat hulle op 'n krampagtige manier die geloofswaarhede voor die regbank van die rede probeer verdedig het. Behalwe in die klassieke skolastieke teologie (sowel Rooms as Protestants) kom hierdie benadering ook in die gereformeerde teologie voor. Met verwysing na V Hepp se destydse intreerede aan die Vrije Universiteit van Amsterdam (1922), herinner Berkouwer ${ }^{1}$ ons aan 'n al te "absolute" toon wat die gereformeerde apologetiek kan inslaan. Teenoor so 'n goedkoop apologetiek is daar egter ook 'n verantwoorde poging moontlik (en gebode) om die verbindingslyne tussen geloof en rede teologies na te vors. So 'n gesonde apologetiek is nie net op die verdediging ingestel nie, maar wil veral die sinvolle kommunikasie tussen die teologie en die kontemporêre wetenskaplike denke dien.

As 'n mens Heyns se teologie deurwerk, is dit duidelik dat hy apologetiek in hierdie laasgenoemde sin verstaan en beoefen het. Ongelukkig het hy nêrens self 'n definisie gegee van wat hy onder apologetiek verstaan nie. Na alle waarskynlikheid sou hy egter met Jonker ${ }^{2}$ se omskrywing kon saamstem: Die taak van die 
apologetiek is om die verskille tussen die hedendaagse wysgerige denke, by name die sekularisme en ateïsme, en die Christelike belydenis aan te toon. Dit het nie ten doel om die geloof op redelike gronde aanneemlik te probeer mak nie, maar om positief te getuig van die Christelike geloofskeuse. Vanweë Heyns se belangstelling en onderlegdheid in die wysbegeerte is dit begryplik dat hy hom juis ook op hierdie onderafdeling van die dogmatologiese vakke sou ingrawe.

Nie een van Heyns se publikasies word eksplisiet as apologetiek aangekondig nie. 'n Mens sou egter talle gedeeltes in sy dogmatiek en etiek as van 'n apologetiese aard kon aanmerk. Vermoedelik beskou hy die dogmatologie as 'n geïntegreerde vakgebied waarin die subdissiplines onderling met mekaar vervleg is ${ }^{3}$. 'n Aantal van sy werke lê egter spesifiek op die terrein van die apologetiek ${ }^{4}$. In die volgende paragrawe word dié boeke een na die ander kronologies aan die orde gestel. Die artikel word afgesluit met 'n kort bespreking van Heyns se bydrae op die gebied van die apologetiek.

\section{DIE EVANGELIE IN KRISIS}

Nadat Heyns sy twee proefskrifte - in die dogmatiek en in die wysbegeerte - voltooi het en 'n aantal kleinere publikasies die lig laat sien het ${ }^{5}$, was sy eerste belangrike boek met die oog op ons ondersoek Die evangelie in krisis (1966) ${ }^{6}$. In sy verantwoording sê hy dat hy daarin die aandag vra vir "die probleem rondom die verhouding van die evangelie en die moderne mens"7 - 'n tipies apologetiese tema. Hy onderskei drie wyses waarop hierdie probleem in die destydse literatuur aangespreek is: 'n aanknoping by, 'n uitbreiding van, en verwerping van die evangelie. Hierdie standpunte skep na sy mening 'n "krisissituasie" vir die evangelie 8 . Dit is veral die eerste van hierdie drie gesigspunte, naamlik die bewustelike poging om 'n vernuwingsteologie uit te bou om aan die behoefte van die mondige mens van ons tyd te voldoen, wat hom interesseer ${ }^{9}$. Dié afdeling van sy boek is gevolglik die uitvoerigste.

Heyns laat al die bekende spelers in die destydse teologiese toneel voor sy lesers optree: Robinson, Bultmann, Bonhoeffer, Tillich, De Chardin, en die verteenwoordigers van die sogenaamde God-is-dood-beweging: Van Buren, Altizer, Hamilton en Vahanian. Op 'n besonder bevatlike manier word die grondlyne van elke teoloog geskets. Elke hoofstukkie word dan met kernagtige kritiek afgesluit, meestal in 'n sterk afwysende sin.

Op twee opvallende punte moet die aandag nog gevestig word. Eerstens is daar Heyns se uitvoerige behandeling van Paul Tillich - dié uitvoerigste in die hele boek. Sou dit veral Tillich se apologetiese metode ${ }^{10}$ en sy worsteling met die verhouding tussen filosofie en teologie ${ }^{11}$ wees wat Heyns besonder geboei het? Nietemin, ook Tillich se standpunt word as onbybels verwerp. Tweedens is daar 
Heyns se behandeling van die Stellenbosse filosoof, J J Degenaar ${ }^{12}$. Dit illustreer dat hy, as egte apologeet, nie geskroom het om die evangelie ook teenoor kritici naby aan huis manmoedig te verdedig nie. Hy het wel simpatie met Degenaar se bedoeling om ' $n$ boodskap vir die mens in sy situasie hier en nou te bring, maar die wyse waarop hy dit wil doen, word "onverbiddelik" afgewys 13 .

In die res van die boek bespreek Heyns meer radikale standpunte soos dié van Karl Jaspers, Friedrich Nietzsche, Jean-Paul Sartre en andere. Selfs die grondleggers van die Kommunisme kry daarin 'n ruim plek. Die publikasiedatum was immers die sterfjaar van dr H F Verwoerd. Die outeur se konklusie is dat ons in die genoemde benaderings met 'n subtiele aanslag op die hart van die evangelie te make het. Juis daarom moet ons ernstige aandag daaraan skenk. Ook ons is geroep om, waar nodig, ons standpunte te "herformuleer" - nie om die behoefte van die moderne mens te bevredig nie, maar omdat 'n gereformeerde kerk "steeds moet reformeer" om gereformeerd te kan wees ${ }^{14}$.

\section{3}

\section{STERWENDE CHRISTENDOM?}

Heyns is in 1966 aangestel as dosent aan die Stellenbosse Kweekskool. Een van die vakke wat aan hom opgedra is, was juis apologetiek. Dit getuig van sy enorme werkywer dat hy reeds in 1969 'n soort van handboek vir dié vak kon publiseer, aan die hand waarvan hy sy lesings aangebied het ${ }^{15}$.

In Sterwende Christendom? bespreek Heyns basies dieselfde tema as in Die evangelie in krisis, maar hierdie keer net op 'n veel breër en meer indringende skaal. In die eerste hoofstuk ("Verkenning") stel die skrywer homself drie dinge ten doel: 'n analise van die moderne tydgees, 'n oorsig oor die eietydse teologie, en 'n beoordeling daarvan ${ }^{16}$. Hierdie werkprogram ag hy noodsaaklik om die "fundamentele probleem" waarmee die gelowige in ons tyd gekonfronteer word aan te spreek. Dit is die - tipies apologetiese - vraagstuk van die verhouding van die Christelike waarhede tot die nuwe werklikheidservaring 1 ?

Heyns se analise van die tydgees mond uit in 'n lang bespreking van die begrippe sekularisasie en sekularisme. Eersgenoemde kon hy positief waardeer as die historiese proses van die mens se kulturele groei en selfstandigwording. Maar laasgenoemde moet negatief gewaardeer word as die prinsipiële standpunt dat die moderne mens so selfstandig van God geword het dat hy self sy eie wetgewer geword het. Kortom: "As sekularisasie verwêreldliking is, is sekularisme verwêreldliking van God en dit is ten diepste gelyk aan vergoddeliking van die wêreld"18. Die historiese agtergronde van hierdie hedendaagse verskynsels word vervolgens nagegaan vanaf die vóor-Christelike tyd via die Middeleeue, Renaissance, Humanisme en Aufklärung tot by die negentiende en twintigste eeuse filosofiese strominge soos positivisme, evolusionisme, liberalisme, pragmatisme en 
eksistensialisme ${ }^{19}$. In hierdie gedeelte het ons die mees uitvoerige en sistematiese uiteensetting by Heyns van die stof wat gewoonlik in die apologetiek aan die orde kom. Dit is terselfdertyd ook 'n sonderlinge voorbeeld van Heyns se vermoë om histories die ontwikkelingsgang van 'n teologiese tema na te vors. Later is hy verwyt omdat hy nie hierdie historiese metode ook in sy dogmatiek volgehou het nie ${ }^{20}$.

Wanneer Heyns in 'n volgende hoofstuk die kenmerke van die eietydse teologie bespreek, tipeer hy dit agtereenvolgens as rasionalisties, anti-metafisies, ateïsties, supra-histories, funksionalisties en personalisties. Onder elke afdeling verwys hy in deeglik gedokumenteerde voetnotas na dieselfde eietydse teoloë wat hy reeds in Die evangelie in krisis behandel het ${ }^{21}$. Die outeur lewer deurgaans bewys van sy wye belesenheid in dié literatuur en sy bedrewenheid om die gedagtegange tot in die fynste besonderhede uit te pluis. Sy kennis van die wysbegeerte het hom daarin sekerlik goed te pas gekom.

In 'n slothoofstuk vat Heyns sy beoordeling van die eietydse teologie in 'n paar hoofpunte saam. Daarmee kom hy, al redenerende, tot 'n eie standpunt. Die eerste wat hy noem, is die motief van die hedendaagse teologie, naamlik om ter wille van kommunikasie solidêr met die moderne mens te wees. Hy sê dat in dié teologie "kommunikasie" volkome "akkommodasie" van die boodskap van die Skrif aan die mens geword het, en dit vind hy 'n onaanvaarbare opheffing van die antitese tussen openbaring en rede 22 . 'n Tweede punt van kritiek raak die metode van die eietydse teologie, wat nie rekening hou met die voorwetenskaplike aard van die Bybelse wêreldbeeld nie 23 . Vervolgens wys Heyns daarop dat die hedendaagse teologie "ook inhoudelik aan die Skrif onnoemlik veel skade aangerig het"24, veral deur die prysgawe van die goddelikheid van Christus. Ten slotte onderskei Heyns ook "belangrike waarheidsmomente" in die eietydse teologie 25 . Dit vind hy formeel in die insig dat teologie altyd histories deur sy konkrete situasie bepaal word, en materieel in die beklemtoning van die wêreldbetrokkenheid van die geloof. Heyns is oortuig dat ons gereformeerdes ook 'n eietydse teologie moet uitbou. Ook ons moet "moderne" teoloë wees - iets totaal anders as "modernistiese" teoloë26. Hy is van mening dat die Bybelse "volheid van die tyd" (Gal 4:4) nie net met die koms van Christus aangebreek het nie. Dit is ook 'n dinamiese begrip: ons sou kon sê die tyd word ál voller en die Christendom self is in 'n ontwikkeling inbegrepe ${ }^{27}$. Om die rede moet 'n eietydse (gereformeerde) teologie ók 'n vernuwingsteologie wees. Hoewel dit nooit "sekularisties" mag wees nie, het dit die plig om voluit "sekulêr" te wees; dit wil sê, die legitieme "aardse of wêreldse" betekenis van die Christelike geloof moet meer as ooit te vore aangetoon word 28 . 
Toe Heyns in 1971 na Pretoria verhuis het, waar hy hoogleraar geword het, het hy langs dieselfde apologetiese lyne sy teologie verder uitgebou. In sy intreerede aan die Universiteit van Pretoria ${ }^{29}$ gaan hy weer in op die "vernuwingsteologie": die oorsake en kenmerke daarvan, asook 'n beoordeling daarvan en ons optrede met betrekking daartoe. Weer eens beklemtoon hy dat daar tussen teologie - ook gereformeerde teologie - en tydgees 'n intieme en onlosmaaklike band bestaan. Teologie is altyd teologie van en vir sy tyd ${ }^{30}$. Om die rede kan ons in Suid-Afrika nie anders as om deeglik kennis te neem van die veranderinge wat in Nederlandse kringe gebeur nie. Terselfdertyd sal ons eie teologiese opleiding "kontemporêr en aktueel" moet wees: ons sal ons studente intensief in die moderne denke moet inlei 31 .

Sy eerste groot werk nadat hy professor geword het, was Lewende Christendom ${ }^{32}$. Hierdie werk is kennelik as 'n opvolging van Sterwende Christendom? bedoel. Dit blyk reeds uit die titels van die twee werke: die tweede een bied 'n antwoord op die vraag in die eerste een. Ook in 'n ander opsig sluit die twee direk bymekaar aan. Dieselfde aspekte waarmee Sterwende Christendom? afgesluit het, vorm nou die inleiding van Lewende Christendom. Ek noem enkeles daarvan. Die verhouding van die Christendom tot die tydgees is nie een van "verbygaan" of "opgaan" nie, maar "ingaan"33. As laasgenoemde weg gevolg word, word die teologie eietyds. Anders gesê: sekularisasie - nie sekularisme nie - moet as "'n egte reformatoriese verstaan van die evangelie" aanvaar word 34 . In aansluiting by die kenmerke van die twintigste eeu moet die Christelike teologie die uitdaging aanvaar om "midde-in hierdie tydgees" gestalte aan die evangelie te gee ${ }^{35}$. Nogeens in aansluiting by die destyds heersende teologiese mode soek Heyns dan na 'n sentrale Bybelse tema wat "as toegangspoort kan dien tot die verstaan en belewing van die Christelike geloof vir die mens van ons dag"36. Dit vind hy in die begrip gehoorsaamheid. Juis omdat die daadkarakter van die geloof vir die moderne mondige mens van sulke groot belang is, én omdat dít terselfdertyd 'n eg-Bybelse opvatting is, kan dit as 'n geskikte invalshoek vir 'n eietydse teologie beskou word ${ }^{37}$ Heyns is bewus daarvan dat gehoorsaamheid, wat gesag impliseer, vir die moderne outonome mens nie so danig aantreklik sal wees nie. Teenoor hierdie bedenking stel hy egter dat "die kategorie van die gehoorsaamheid as uitdrukking van die afhanklikheidsbetrekking van die mens teenoor God of sy gode (.....) só seer eie is aan alle godsdienste dat dit die moeite loon om gehoorsaamheid ook binne die Christelike godsdiens as boodskap vir die mens van ons dag te ondersoek"38.

Hierdie gedagtegang van Heyns nooi die ondersoeker eintlik uit om met hom in gesprek te tree. Die finale beoordeling daarvan bêre ek vir my laaste paragraaf. Maar waarop nou reeds die aandag gevestig moet word, is dat Heyns 
hiermee voluit apologeties te werk gaan. Sy antwoord word tot op groot hoogte bepaal deur die vrae van die moderne mens - hoewel nie volledig nie, want hy is nog altyd bereid om die eietydse behoeftes ook vanuit die Bybel téén te gaan. Maar daarvoor soek hy dan tog weer - tipies apologeties - in méér as die Bybel sy gronde. Selfs die vergelykende godsdienswetenskap word as 'n getuie ingeroep.

Die res van Lewende Christendom is 'n eksegetiese en tetiese uiteensetting van die teologiese begrip gehoorsaamheid, respektiewelik koninkryk. As sodanig staan daar baie belangrike gegewens in vir die verstaan van Heyns se teologie. Maar weinig daarvan het direk betrekking op die afgebakende onderwerp van hierdie ondersoek.

DIE MENS

Heyns se monografie oor die mens ${ }^{39}$ is seker nie so 'n opwindende werk soos die voorafgaandes wat ons hier bespreek het nie. Omdat dit, streng gesproke, nie 'n werk oor die apologetiek is nie, maar oor die antropologie, hoef ons dit ook nie uitvoerig te bespreek nie.

Daar is egter 'n paar redes waarom ons tog, sy dit dan terloops, daarna moet verwys. Eerstens is dit interessant om raak te sien dat Heyns ook hier 'n "apologetiese" metode hanteer. Anders as wat die subtitel van die boek suggereer, behandel hy éérs die buite-Bybelse mensbeskouinge, voordat hy die Bybelse mensbeskouing aan die orde stel. Hy sê dat hy juis hierdie weg volg omdat in die sestal buite-Bybelse beskouinge wat hy gekies het (dualisties, humanisties, eksistensialisties, liberalisties, nasionaal-sosialisties en kommunisties) "besonder waardevolle gesigspunte na vore kom, waaruit positief en negatief veel geleer kan word" 40 . Hulle vorm dus die konteks waarin Heyns sy siening van die Bybelse mensbeskouing wil laat grondvat.

Nog 'n rede waarom Die mens by ons ondersoek betrek moet word, is die feit dat Heyns self die navorsing wat hy daarin onderneem het agteraf as apologetiek tipeer. Hy skryf naamlik dat "in die apologetiek deeglike en indringende aandag" aan die wyd-uiteenlopende buite-Bybelse antropologieë gegee moet word ${ }^{\mathbf{4 1}}$. Vir Heyns se eie verstaan van die taak van die apologetiek is dié opmerking belangrik.

'n Laaste rede waarom hier na Die mens verwys word, is daarin geleë dat Heyns uitdruklik in die inleiding van dié boek sê dat sy werkswyse "nie noodwendig 'n polemiese karakter" impliseer nie ${ }^{42}$. Beteken dit dus dat Heyns "apologeties" in 'n gunstige, maar "polemies" in 'n ongunstige lig beskou? En hoe onderskei hy presies tussen apologetiek en polemiek? Op hierdie saak word daar verderaan weer ingegaan. 
$\mathrm{Na} 1972$ het die apologetiese fase van Heyns se teologiese loopbaan geleidelik tot 'n einde gekom. Hy sou hom voortaan, te midde van 'n druk program, veral toespits op die uitwerk van sy Dogmatiek en Etiek. Nietemin het daar nog een pennevrug van hom verskyn wat spesifiek op die terrein van die apologetiek lê, naamlik Teologie van die revolusie ${ }^{43}$. Dit is nie bedoel as 'n streng wetenskaplike werk nie, want voetnotas word nie daarin gebruik nie. Heyns kom ook nie daarin met nuwe gedagtes oor apologetiese kwessies na vore nie. Ten minste in een opsig is dit egter vir ons ondersoek belangrik: dit bewys dat Heyns ook bereid was om nuwe ontwikkelinge op die teologiese toneel onder die loep te neem en hom daaroor te verantwoord. Veral sy deeglike bespreking van die filosofiese agtergronde van die teologie van die revolusie soos dit na vore kom by neo-Marxistiese denkers soos Herbert Marcuse en Ernst Bloch is in hierdie verband belangrik ${ }^{44}$. Dit kan as 'n waardevolle aanvulling op sy vorige apologetiese arbeid beskou word.

Terwyl ons tog nou kennis neem van Teologie van die revolusie is dit interessant om op te merk hoe konsekwent Heyns sy reeds ingenome standpunte volhou. So skryf hy byvoorbeeld in die inleiding van hierdie boek: "Natuurlik is verandering van die teologie wat op sy vernuwing uitloop, ons Godgegewe roeping en taak en vind dit dan ook uitdrukking in ons ideaal van voortdurende reformasie, maar dan sal ons skerp moet onderskei tussen ware vernuwing en valse vernuwing, tussen spekulatiewe denke en Bybelsgetroue denke". So 'n Heynsiaanse volsin verwoord klokhelder die skrywer se intensie met die onderhawige boek. Tewens, dit is ook 'n goeie omskrywing van sy apologetiese posisiekeuse. Nog 'n voorbeeld van Heyns se konsistensie is die herhaling van sy onderskeiding tussen sekulêr en sekularisties ${ }^{45}$. Ook uit die manier waarop hy die leerstellinge van die teologie van die revolusie beoordeel, leer ons hom weer eens ken as die gebalanseerde volwasse navorser wat telkens woorde van waardering uitspreek, maar tegelykertyd ook skerp kan kritiseer. So kan hy byvoorbeeld in hulle mensbeskouing die volgende aksente waardeer: die mens se werklikheidsbetrokkenheid, sy verantwoordelikheid vir die wêreld én vir sy naaste - "dit alles is vir die antropologie van die grootste belang." Daarteenoor verwerp hy onder meer dié nuwe teologie se "grensloos optimistiese mensbeskouing", asook hulle knieval voor die gevaar van "sinkretisme", waarin Christelike met buite-Christelike waarhede tot 'n eenheid vermeng word ${ }^{46}$. Ek volstaan met 'n laaste voorbeeld van Heyns se standpunt. Op grond van 'n goeie eksegese van die gelykenis van die barmhartige Samaritaan kom hy tot die gevolgtrekking dat dit vir Jesus (anders as vir die teologie van die revolusie) steeds gegaan het om "die primaat van die mens bó die strukture." En tog gaan dit vir Jesus 6́6k om strukture. "Hoe anders dan? sou ons wou vra. Die Heer-wees van Jesus raak 
immers die ganse wêreld en so wyd as wat Sy heerskappy strek, so wyd is die opdrag aan die mens om Hom sigbaar teenwoordig te maak"47.

Onder hierdie opskrif word ten slotte verwys na Heyns se jongste publikasie: Inleiding tot die dogmatiek ${ }^{48}$. Uiteraard moet ons daarmee rekening hou dat dit bedoel is as ' $n$ inleiding vir beginnerstudente. Soos die skrywer in sy Voorwoord sê, het hy "onnodig moeilike vaktaal" doelbewus vermy. Tog is dit vir ons ondersoek belangrik omdat Heyns hierin die enigste uitdruklike definisie van apologetiek gee. Hy verduidelik die "apologetiese aspek", wat hy aan die bespreking van die meeste artikels van die Nederlandse Geloofsbelydenis toevoeg, soos volg: "Deur die eeue heen het daar ook Bybelafwykende beskouinge ontstaan - beskouinge wat hulle wel op die Bybel beroep, maar dan nie 'n suiwere interpretasie of uitleg van die Bybel gee nie. Of ook opvattinge wat buite die Bybel ontstaan het, en dan skerp kritiek lewer teen Bybelse voorstellinge. Verdediging van eie standpunte ook teenoor ander standpunte en trouens ook direkte weerlegging daarvan, is eweneens deel van die taak van die dogmatiek. Dit kan genoem word die apologetiese aspek"49. Hieruit moet ons twee afleidings mak. Die eerste is dat Heyns nie duidelik onderskei tussen, wat tradisioneel genoem word, polemiek en apologetiek nie. En die tweede is dat hy die term "dogmatiek" as 'n wisselterm gebruik vir, wat gewoonlik genoem word, "dogmatologie" - verstaan as 'n versamelnaam vir die dogmatologiese vakgroep 50 . Derhalwe bly dit onduidelik of apologetiek as 'n subdissipline van of naas dogmatiek beskou moet word.

Dat Heyns nie skerp tussen polemiek en apologetiek onderskei nie, kan op verskillende plekke in sy Inleiding tot die dogmatiek aangedui word. By sy bespreking van die Drie-eenheid van God vermeld hy - onder die opskrif "apologeties" - die volgende sektariese standpunte: Unitariërs, Jehovagetuies, Christian Science en Mormone ${ }^{51}$. Normaalweg sal hierdie afwykende strominge egter eerder in die polemiek behandel word. Nog so 'n voorbeeld is by sy behandeling van die regverdiging deur die geloof alleen. Onder die opskrif "apologeties" word daar dan sowel na die piëtistiese en die metodistiese opvattings, as die filosofiese siening van Karl Jaspers - alles in een asem - verwys ${ }^{52}$. Dit is egter 'n vraag of dié temas almal as apologetiese temas beskou kan word. Aan die ander kant is Heyns weer korrek as hy na aanleiding van die sakramente verwys na $G$ van der Leeuw wie se sakramentsteologie teruggaan op 'n filosofiese uitgangspunt 53 . Elders sê hy ook - in verband met die antropologie - dat die "teologiese apologetiek" hom besig moet hou met die humanistiese "filosofiese denke", en dan verwys hy na Jean Jacques Rousseau 54.

Hoewel Heyns dus nie altyd skerp onderskei wat presies onder apologetiek verstaan moet word nie, lewer sy jongste boek ten minste die bewys dat 
apologetiek vir hom enduit deur sy aktiewe teologiese loopbaan 'n saak van groot erns en belang was.

\section{GEVOLGTREKKING}

Ons begroting van die waarde van Heyns se bydrae in die veld van die apologetiek kan begin met die kritiese opmerkings waarmee ons die vorige paragraaf afgesluit het. Dit moet as 'n leemte aangemerk word dat hy nêrens - sover aan my bekend 'n gefundeerde omskrywing gegee het van wat hy onder apologetiek verstaan nie. En waar hy wel 'n poging daartoe aanwend - soos ons gesien het - munt dit nie juis uit in helderheid nie. Hierdie feit het ons ondersoek bemoeilik. 'n Mens weet nie mooi waar apologetiek in Heyns se teologie begin en waar dit eindig nie. Daarom sal 'n ander navorser miskien na ander fasette in Heyns se teologie verwys om hom as apologeet te beskryf. Een van die jonger geslag sal dit sy taak moet maak om behoorlik vir ons uit te klaar wat teologiese apologetiek is, in onderskeiding van onder meer Christelike wysbegeerte, godsdiensfilosofie, polemiek, en dogmatiekgeskiedenis.

Desnieteenstaande hierdie leemte het Heyns aan die ander kant in sommige van sy werke, by name Sterwende Christendom? en Lewende Christendom, 'n definitiewe bydrae tot die gereformeerde apologetiek gelewer. Sy voorbeeld in hierdie verband is sowel formeel as materieel navolgenswaardig. Wat die formele betref, is dit veral die deeglike historiese oorsig van die lewensbeskoulike en filosofiese agtergronde van die eietydse teologie in Sterwende Christendom? wat 'n mens aantrek. Om dit te kan onderneem moet die teoloog ook in die wysbegeerte onderlê wees. Heyns se kennis van dié vakgebied, en by name van die Christelike wysbegeerte, het daartoe bygedra dat hy 'n goeie apologeet kan wees. Uiteraard behoort so 'n aanloop ook aangevul te word met 'n gedetailleerde ontleding van die verteenwoordigers van die kontemporêre teologiese strominge - wat Heyns dan ook gedoen het. Daarbenewens het hy die vrae wat uit so 'n ondersoek na vore kom deeglik van' $n$ antwoord bedien in Lewende Christendom. Sy antwoord is meestal teologies goed verantwoord. Die beskuldiging wat soms gehoor word dat Heyns sy teologie deur die wysbegeerte laat oorheers het, geld dus nie hier nie.

Maar ook inhoudelik, het ons gesê, het Heyns hom goed van sy apologetiese taak gekwyt. Oor die algemeen het hy deurgaans by die gereformeerde belydenis gebly. Hier en daar loop hy miskien gevaar om hom 'n bietjie op sleeptou te laat neem deur die problematiek van destyds waarmee hy so intens geworstel het. Dit is egter' $n$ uitsondering. Om een daarvan te noem: die entoesiasme waarmee Heyns destyds oor die "dinamiese" aspek van "die volheid van die tyd" geskryf het ${ }^{55}$, openbaar waarskynlik meer van die destydse optimistiese tydgees, in die middel van ons eeu, as wat dit regtig die Bybel naspreek. Nou, aan die einde van die eeu, is ons 
as Christene minder optimisties en sal ons ook meer beskeie oor die ontwikkeling in die wêreld praat. Redelik gevaarlike stellings kom veral ook in sy uitdagende werk Lewende Christendom voor ${ }^{56}$. Wanneer 'n mens dié boek lees, hou jy soms jou hart vas. In sommige passasies lyk Heyns soos 'n sirkuskunstenaar wat met 'n lang stok homself op 'n styfgespande draad moet balanseer. Net wanneer jy dink hy gaan val, bly hy tog regop... deur die genade! Dit gebeur veral waar hy oor die mens se verhouding tot God handel en begrippe soos "bondgenootskap", "vennote" en "medewerkers met God" gebruik ${ }^{57}$. Veral as jy daaraan dink hoe mense soos $\mathrm{H}$ Berkhof en H M Kuitert later dieselfde begrippe sou aanwend om die gereformeerde belydenis te ondergrawe, besef jy hoe 'n riskante onderneming die apologetiek kan wees.

'n Ander interessante kwessie by die oorweging van Heyns se apologetiek is die vraag of daar by hom sprake van 'n ontwikkeling in sy beskouinge was. Uiteraard het hy hom algaande breër en dieper in dié vakgebied georiënteer. Wat sy eie standpunte betref was hy, soos ons gesien het, konsekwent en het hy nie nodig gehad om later vroeëre keuses te repudieer nie. Dit getuig nogeens van sy weldeurdagtheid.

Heyns het nie in die laaste fase van sy loopbaan sy apologetiese insigte uitgebou en afgerond, soos hy wel met die dogmatiek en die etiek gemaak het nie. Ook sy beste werk in dié veld vertoon daarom vandag, na twee dekades, 'n sekere tydgebondenheid. Die noodwendigheid van die eietydsheid van die teologie het hy egter self erken. Hy kan daarom nie daarvoor kwalik geneem word nie. Dit is egter jammer dat hy hoofsaaklik met 'n bespreking van die teologiese strominge van die sestiger- en sewentigerjare volstaan het. Wie vandag apologetiek wil bedryf, sal immers ook aan die nuutste tendense aandag moet gee. Dan dink 'n mens veral aan die hedendagse paradigmaverskuiwing op internasionale vlak by denkers soos $\mathrm{H}$ Küng en D Tracy. Hoe jammer is dit dat ons nie meer Johan Heyns se ontleding en beoordeling van byvoorbeeld die invloed van die postmodernisme op die teologie sal kan lees nie. Of gaan hy ons miskien nog verras met 'n nuwe boek oor die nuutste teologie?

\section{NOTAS:}

1 G C Berkouwer, Een halve eeuw theologie, Kampen 1974, 29-48.

2 J A Heyns en W D Jonker, Op weg met die teologie, Pretoria 1974, 295 ev.

3 Vergelyk sy mees resente publikasie, Inleiding tot die dogmatiek, Halfway House 1992. Daarin behandel hy"naas onder meer die "tetiese" en "etiese" fasette ook die "apologetiese" faset van elke artikel van die Nederlandse Geloofsbelydenis.

$4 \quad$ P B van der Watt, "Prof dr Johan Adam Heyns - anno sexagesimo", in: ' $n$ Woord op sy tyd ('n Teologiese Feeshundel aangebied aan professor Johan 
Heyns ter herdenking van sy sestigste verjaarsdag, onder redaksie van $C J$ Wethmar en C J A Vos), Pretoria 1988, 3, noem in die verband slegs Denkers deur die eeue (1967), Sterwende Christendom? (1969) en Lewende Christendom (1972). Myns insiens is daar egter meer. Buitendien is dit 'n vraag of die eerste een wat Van der Watt noem regtig 'n aparte bespreking regverdig. Denkers deur die eeue, Kaapstad 1967, is inderdaad 'n lesenswaardige boek. Maar as sodanig is dit nie teologiese apologetiek nie, al word daarin ook 'n aantal teoloë soos Augustinus, Thomas, Calvyn en Barth behandel. Blykbaar het die outeur meer ' $n$ inleidende populêre leesboek in gedagte gehad. Daarom bespreek hy ook 'n aantal filosowe soos Confucius, Rousseau en Sartre wat nie 'n direkte invloed op die Christelike teologie gehad het nie. Uit 'n biografiese oogpunt is dit wel belangrik om te lees met watter bewondering Heyns die Potchefstroomse Calvinistiese wysgeer, H G Stoker, as die laaste denker in dié boek aan die woord stel.

5 Vergelyk Rian Venter, "Bibliografie: J A Heyns" in: 'n Woord op sy tyd, Pretoria 1988, 238-245.

6 J A Heyns, Die evangelie in krisis, Kaapstad 1966.

7 Heyns, $a w, 1966,7$.

8 Heyns, $a w, 1966,7-8$.

9 Heyns, $a w, 1966,11$.

10 Heyns, $a w, 1966,51-53$.

11 Heyns, $a w, 1966,66$.

12 Heyns, $a$ w, 1966, 86-94.

13 Heyns, $a w, 1966,93$.

14 Heyns, a w, 1966, 140.

15 J A Heyns, Sterwende Christendom? 'n Teologie in die greep van die tydgees, Kaapstad 1969.

$16 \quad$ Heyns, $a w, 1969,18$.

17 Heyns, $a w, 1969,11$.

18 Heyns, $a w, 1969,31$.

19 Heyns, $a w, 1969,33-95$.

20 W D Jonker sê in 'n resensie van Heyns se Dogmatiek (1978), NGTT, 21/2 (1980), 195, dat dit vir homself baie belangrik is om "die historiese en teologiese agtergrond van die dogma bloot te lê".

21 Heyns, $a$ w, 1969, 96-160. 
22 Heyns, $a w, 1969,162,164$.

23 Heyns, $a w, 1969,167$.

24 Heyns, $a w, 1969,173$.

25 Heyns, $a w, 1969,178$.

26 Heyns, $a w, 1969,181$.

27 Heyns, $a w, 1969,182$.

28 Heyns, $a w, 1969,183$.

29 J A Heyns, Die huidige stand van die gereformeerde teologie in Nederland en ons verantwoordelikheid, Pretoria 1971.

30 Heyns, $a w, 1971,6,31$.

31 Heyns, $a w, 1971,34-35$.

32 J A Heyns, Lewende Christendom. 'n Teologie van gehoorsaamheid, Kaapstad 1972.

33 Heyns, $a w, 1972,4$.

$34 \quad$ Heyns, $a w, 1972,8$.

35 Heyns, $a w, 1972,15$.

36 Heyns, $a w, 1972,21$.

37 Ibid.

38 Heyns, $a w, 1972,22$.

39 J A Heyns, Die mens. Bybelse en buite-Bybelse mensbeskouinge, Bloemfontein 1974.

$40 \quad$ Heyns, $a w, 1974,9$.

41 J A Heyns, $a w, 1992$, 188-189 - weliswaar sonder 'n uitdruklike verwysing na Die mens.

42 Heyns, $a w, 1974,8$.

43 J A Heyns, Teologie van die revolusie, Kaapstad 1975.

44 Heyns, $a w, 1975,17-28$.

45 Heyns, $a w, 1975,45$.

46 Heyns, $a w, 1975,71$. 
Heyns, $a w, 1975,101-102$.

$48 \mathrm{~J}$ A Heyns, Inleiding tot die dogmatiek aan die hand van die Nederlandse Geloofsbelydenis, Halfway House 1992.

49 Heyns, $a w, 1992,2$.

50 Weliswaar gebruik Heyns, $a w, 1992,32$, die tradisionele onderskeiding tussen polemiek en apologetiek. Eersgenoemde behandel "die onderlinge verskille tussen Christene oor die dogmata", en laasgenoemde is "die verdediging van die dogmata teen aanvalle van buite die Christendom". Dit klop met Jonker se omskrywing in $O p$ weg met die teologie (vergelyk voetnota 2 hierbo). Maar in die res van Heyns, $a w, 1992$, funksioneer hierdie onderskeiding nie.

$51 \quad$ Heyns, $a w, 1992,128$.

52 Heyns, $a w, 1992,272$.

53 Heyns, $a w, 1992,374$.

$54 \quad$ Heyns, $a w, 1992,198$.

55 Vergelyk die aanhalings teen die einde van my paragraaf 3 hierbo.

56 Vergelyk die kritiese vrae teen die einde van my paragraaf 4 hierbo.

57 Heyns, $a w, 1972,95-108$. 